http://jmscr.igmpublication.org/home/ ISSN (e)-2347-176x ISSN (p) 2455-0450

crossref DOI: https://dx.doi.org/10.18535/jmscr/v9i1.46

\title{
Comparison of Findings of Autorefraction and Retinoscopy with Subjective acceptance between Rural and Urban School going Children in Northern India
}

\section{Authors \\ Shiraz Ahmad Bhat ${ }^{1}$, Vijender Kour ${ }^{2}$, Tajali Mushtaq ${ }^{3}$}

\begin{abstract}
Purpose: To compare spectrum of autorefraction and retinoscopy with subjective acceptance between rural and urban school going children.

Materials and Methods: A total of 100 Children between 6-16 years of age were included in this study (50 rural 50 urban). Findings of autorefraction and retinoscopy with subjective acceptance were calculated and compared between the two groups.

Results: Out of 100 children 22\% were in the age group of 6-8 years, 30\% in the age group of 9-11 years with a frequency of $30 \%$ and $34 \%$ in the age group of $12-14$ years and $14 \%$ of $\geq 15$ years. The mean age was 11.2 years. Dry autorefractometer over corrects refractive error in comparison to subjective acceptance. In our study of wet autorefraction and subjective acceptance myopia has mean of -2.27 with subjective acceptance of 2.03 whereas in hypermetropia has mean of 2.81 with acceptance 2.52 in right eye. In comparison of dry retinoscopy with subjective acceptance myopia of right eye has mean of -0.99 with SD-2.03 and hyperopia of 3.49 with SD 2.52. In comparison of wet retinoscopy with subjective acceptance which shows $P$ value of $<0.05$ which is clinically insignificant.

Conclusion: We concluded from this study that autorefractometer over estimates refractive errors but there was no significant difference between wet retnoscopy and subjective acceptance. So according to this study we suggest use of cycloplegic retnoscopy with subjective acceptance in determining refractive errors in children.
\end{abstract}

\section{Introduction}

Detection and correction of refractive errors in children is very important for preventing irreversible vision loss secondary to suppression of a blurred or unfocused retinal images (amblyopia) and to eliminate any visual impairment which is harmful to the child's normal functioning in daily life. Cycloplegic retinoscopy and subjective refraction remain the gold standard for measuring refractive status in children however, the cycloplegia is limited by the time need to achieve full cycloplegia, its association with patient discomfort, inconvenience and additional cost. Measurements of refractive errors can be made with different techniques of measurement \& various accommodation control methods. Assessment of refractive error in the paediatric population can be challenging, even for an experienced optometrist. More recently autorefractors without cycloplegiahas become widely used to obtain objective refractive status of children in vision screening, clinical practice and clinical trials. The traditional method for identify refractive errors in children includes 
noncycloplegic and cycloplegic retinoscopy and autorefractometer which performed by skilled experienced ophthalmologist. Conventional retinoscopy requires long training for examiners and cooperative patients. Therefore, there has been an effort to develop techniques and instruments that permit detection of refractive errors with minimal requirement of cooperation in children. Autorefractors are frequently used as are ference in subjective refractions in optometric and ophthalmological practice for spectacle prescription. The popularity of autorefractometers in clinical practice lies in their ease of use, good results, and great acceptance among clinicians and patients. These instruments currently range from portable to sophisticated multifunction devices which can measure ocular parameters such as radius of curvature or aberrations. The accuracy of autorefractometers has been evaluated and compared with reference values.

Usually obtained by subjective refraction or retinoscopy. Most studies concluded that differences in accuracy between autorefractometers had become very small, although a myopic shift appeared with some of them because accommodation could not be reliably relaxed. Previous studies established that the majority of modern autorefractometers are highly accurate compared to subjective refraction in adult patients. Other authors found that under noncycloplegicconditions, autorefractometers had a tendency towards minus overcorrection in children and that their accuracy increased under cycloplegic conditions. Our study aims at comparing the retinoscopy and autorefractometery in rural and urban children.

\section{Materials and Methods}

This study was carried out at a tertiary eye care hospital in northern India from February 2019 to November 2019. A total of 100 children were studied (50 rural 50 urban ). Patients of both sexes aged 6-16 years were included in this study.

\section{Results}

Out of 100 children $22 \%$ were in the age group of 6-8 years, $30 \%$ in the age group of 9-11 years with a frequency of $30 \%$ and $34 \%$ in the age group of $12-14$ years and $14 \%$ of $\geq 15$ years. The mean age was 11.2 years.

Dry autorefractometer over corrects refractive error in comparison to subjective acceptance. In our study of wet autorefraction and subjective acceptance myopia has mean of -2.27 with subjective acceptance of 2.03 whereas in hypermetropia has mean of 2.81 with acceptance 2.52 in right eye. In comparison of dry retinoscopy with subjective acceptance myopia of right eye has mean of -0.99 with SD-2.03 and hyperopia of 3.49 with SD 2.52. In comparison of wet retinoscopy with subjective acceptance which shows $\mathrm{P}$ value of $<0.05$ which is clinically insignificant.

Table 1: Showing uncorrected visual acuity (UCVA) of study eyes

\begin{tabular}{|l|c|c|c|c|}
\hline \multirow{2}{*}{ UCVA } & \multicolumn{2}{|c|}{ Right Eye } & \multicolumn{2}{c|}{ Left Eye } \\
\cline { 2 - 5 } & No. & \%age & No. & \%age \\
\hline $\mathbf{0 . 0 - 0 . 3}$ & $\mathbf{5 1}$ & $\mathbf{5 1 \%}$ & $\mathbf{4 8}$ & $\mathbf{4 8 \%}$ \\
\hline $\mathbf{0 . 4 - 0 . 6}$ & $\mathbf{2 7}$ & $\mathbf{2 7 \%}$ & $\mathbf{3 0}$ & $\mathbf{3 0 \%}$ \\
\hline $\mathbf{0 . 7 - 0 . 9}$ & $\mathbf{1 5}$ & $\mathbf{1 5 \%}$ & $\mathbf{1 4}$ & $\mathbf{1 4 \%}$ \\
\hline$>\mathbf{0 . 9}$ & $\mathbf{7}$ & $\mathbf{7 \%}$ & $\mathbf{8}$ & $\mathbf{8 \%}$ \\
\hline Total & $\mathbf{1 0 0}$ & $\mathbf{1 0 0 \%}$ & $\mathbf{1 0 0}$ & $\mathbf{1 0 0 \%}$ \\
\hline Mean \pm SD (Range) $=11.2 \pm 2.95(6-16)$ &
\end{tabular}


Table 2: Showing comparison between dry autorefraction and subjective acceptance in study eyes

\begin{tabular}{|c|c|c|c|c|c|c|}
\hline \multirow[t]{2}{*}{ Eye } & \multirow[t]{2}{*}{ Error } & \multicolumn{2}{|c|}{$\begin{array}{c}\text { Dry } \\
\text { Auto refraction }\end{array}$} & \multicolumn{2}{|c|}{$\begin{array}{c}\text { Subjective } \\
\text { Acceptance }\end{array}$} & \multirow[t]{2}{*}{ P - Value } \\
\hline & & Mean & SD & Mean & SD & \\
\hline \multirow{4}{*}{$\begin{array}{l}\text { Right } \\
\text { eye }\end{array}$} & Myopia & -2.19 & 1.294 & -2.03 & 1.274 & 0.635 \\
\hline & Hypermetropia & 2.73 & 1.506 & 2.52 & 1.477 & 0.602 \\
\hline & $\begin{array}{c}\text { Myopic } \\
\text { Astigmatism }\end{array}$ & -2.23 & 1.089 & -2.20 & 1.123 & 0.960 \\
\hline & $\begin{array}{c}\text { Hypermetropic } \\
\text { Astigmatism }\end{array}$ & 1.38 & 0.750 & 1.13 & 0.777 & 0.660 \\
\hline \multirow{4}{*}{$\begin{array}{l}\text { Left } \\
\text { eye }\end{array}$} & Myopia & -2.26 & $\mathbf{1 . 3 3 2}$ & -2.04 & 1.278 & 0.523 \\
\hline & Hypermetropia & 2.99 & 1.523 & 2.81 & 1.532 & 0.658 \\
\hline & $\begin{array}{c}\text { Myopic } \\
\text { Astigmatism }\end{array}$ & -2.53 & 1.935 & -2.43 & 1.555 & 0.9 \\
\hline & $\begin{array}{c}\text { Hypermetropic } \\
\text { Astigmatism }\end{array}$ & 1.44 & 0.875 & 1.13 & 0.777 & 0.613 \\
\hline
\end{tabular}

Table 3: Showing comparison between wet autorefraction and subjective acceptance in study eyes

\begin{tabular}{|c|c|c|c|c|c|c|}
\hline \multirow[t]{2}{*}{ Eye } & \multirow[t]{2}{*}{ Error } & \multicolumn{2}{|c|}{$\begin{array}{c}\text { Wet } \\
\text { Auto refraction }\end{array}$} & \multicolumn{2}{|c|}{$\begin{array}{c}\text { Subjective } \\
\text { Acceptance }\end{array}$} & \multirow[t]{2}{*}{ P - Value } \\
\hline & & Mean & SD & Mean & $\mathrm{SD}$ & \\
\hline \multirow{4}{*}{$\begin{array}{l}\text { Right } \\
\text { eye }\end{array}$} & Myopia & -2.27 & 1.26 & -2.03 & 1.27 & 0.478 \\
\hline & Hypermetropia & 2.81 & 1.47 & 2.52 & 1.48 & 0.463 \\
\hline & $\begin{array}{c}\text { Myopic } \\
\text { Astigmatism } \\
\end{array}$ & -2.28 & 1.17 & -2.20 & 1.12 & 0.885 \\
\hline & $\begin{array}{c}\text { Hypermetropic } \\
\text { Astigmatism }\end{array}$ & 1.56 & 0.80 & 1.13 & 0.78 & 0.463 \\
\hline \multirow{4}{*}{$\begin{array}{l}\text { Left } \\
\text { eye }\end{array}$} & Myopia & -2.28 & 1.34 & -2.04 & 1.28 & 0.478 \\
\hline & Hypermetropia & 3.13 & 1.64 & 2.81 & 1.53 & 0.457 \\
\hline & $\begin{array}{c}\text { Myopic } \\
\text { Astigmatism }\end{array}$ & -2.53 & 1.93 & -2.35 & 1.64 & 0.830 \\
\hline & $\begin{array}{c}\text { Hypermetropic } \\
\text { Astigmatism }\end{array}$ & 1.44 & 0.38 & 1.13 & 0.78 & 0.496 \\
\hline
\end{tabular}

Table 4: Showing comparison between dry retinoscopy and subjective acceptance in study eyes

\begin{tabular}{|c|c|c|c|c|c|c|}
\hline \multirow[t]{2}{*}{ Eye } & \multirow[t]{2}{*}{ Error } & \multicolumn{2}{|c|}{$\begin{array}{c}\text { Dry } \\
\text { Retinoscopy }\end{array}$} & \multicolumn{2}{|c|}{$\begin{array}{c}\text { Subjective } \\
\text { Acceptance }\end{array}$} & \multirow[t]{2}{*}{ P - Value } \\
\hline & & Mean & SD & Mean & SD & \\
\hline \multirow{4}{*}{$\begin{array}{l}\text { Right } \\
\text { eye }\end{array}$} & Myopia & $\begin{array}{l}-0.99 \\
\end{array}$ & 1.227 & -2.03 & 1.274 & 0.002 \\
\hline & Hypermetropia & 3.49 & 1.514 & 2.52 & 1.477 & 0.021 \\
\hline & $\begin{array}{c}\text { Myopic } \\
\text { Astigmatism }\end{array}$ & -1.03 & 0.953 & -2.20 & 1.123 & 0.023 \\
\hline & $\begin{array}{c}\text { Hypermetropic } \\
\text { Astigmatism }\end{array}$ & 2.00 & 1.021 & 1.13 & 0.777 & 0.221 \\
\hline \multirow{4}{*}{$\begin{array}{l}\text { Left } \\
\text { eye }\end{array}$} & Myopia & -1.01 & 1.243 & -2.04 & 1.278 & 0.002 \\
\hline & Hypermetropia & 3.66 & 1.699 & 2.81 & 1.532 & 0.048 \\
\hline & $\begin{array}{c}\text { Myopic } \\
\text { Astigmatism }\end{array}$ & -1.35 & 1.475 & -2.53 & 1.635 & 0.035 \\
\hline & $\begin{array}{c}\text { Hypermetropic } \\
\text { Astigmatism }\end{array}$ & 2.00 & 1.021 & 1.13 & 0.777 & 0.221 \\
\hline
\end{tabular}


Table 5: Showing comparison between wet retinoscopy and subjective acceptance in study eyes

\begin{tabular}{|c|c|c|c|c|c|c|}
\hline \multirow[t]{2}{*}{ Eye } & \multirow[t]{2}{*}{ Error } & \multicolumn{2}{|c|}{$\begin{array}{c}\text { Wet } \\
\text { Retinoscopy }\end{array}$} & \multicolumn{2}{|c|}{$\begin{array}{c}\text { Subjective } \\
\text { Acceptance }\end{array}$} & \multirow[t]{2}{*}{ P - Value } \\
\hline & & Mean & SD & Mean & SD & \\
\hline \multirow{4}{*}{$\begin{array}{l}\text { Right } \\
\text { eye }\end{array}$} & Myopia & -1.01 & 0.813 & -2.03 & 1.274 & $<0.001$ \\
\hline & Hypermetropia & 4.19 & 1.601 & 2.52 & 1.477 & $<0.001$ \\
\hline & $\begin{array}{c}\text { Myopic } \\
\text { Astigmatism }\end{array}$ & -0.55 & 1.28 & -2.20 & 1.12 & 0.007 \\
\hline & $\begin{array}{c}\text { Hypermetropic } \\
\text { Astigmatism }\end{array}$ & 2.75 & 1.02 & 1.13 & 0.78 & 0.044 \\
\hline \multirow{4}{*}{$\begin{array}{l}\text { Left } \\
\text { eye }\end{array}$} & Myopia & -1.03 & 0.802 & -2.04 & 1.278 & $<0.001$ \\
\hline & Hypermetropia & 4.53 & 1.528 & 2.81 & 1.532 & $<0.001$ \\
\hline & $\begin{array}{c}\text { Myopic } \\
\text { Astigmatism }\end{array}$ & -0.93 & 1.86 & -2.53 & 1.93 & 0.046 \\
\hline & $\begin{array}{c}\text { Hypermetropic } \\
\text { Astigmatism }\end{array}$ & 2.75 & 1.02 & 1.13 & 0.78 & 0.034 \\
\hline
\end{tabular}

\section{Discussion}

Refractive errors are common among children and refraction is a widely developed process because of this ${ }^{1}$. Cycloplegic retinoscopy and subjective refraction are the standard methods of diagnosing refractory errors in children ${ }^{2}$. The refractometry is an alternative method of finding out the errors of refraction by use of optical equipment called autorefractometer or optometer ${ }^{3}$. Recently, new generation of autorefractometers are designed to substitute the conventional technique of retinoscopic refraction. These new designs are claimed to have good repeatability and validity of both spherical and astigmatic error measuremets ${ }^{4-}$ 7

The autorefractometers are new, easy to use, acceptable and popular in the recent times. However, when using autorefractometers, the accommodative effort that is employed can lead to minus over correction. This can lead to wrong diagnosis. If there is a minus overcorrection, it can lead to myopic progression among children ${ }^{8-10}$.

Jorge J, et al. ophthalmic physiol opt. (2005) ${ }^{11}$ The purpose of this study was to compare refractions measured with an autorefractor and by retinoscopy with or without cycloplegia. The objective refractions were performed in 199 right eyes from 199 healthy young adults with a mean age of $21.6+2.66$ years. The measurements were performed first without cycloplegia and repeated 30 minutes later with cycloplegia. The study confirm that when performed by an experienced clinician, retinoscopy is a more reliable method to obtain the objective refraction. Mallen EA, et al (2001) ${ }^{12}$ A clinical evaluation of the Shin- Nippon SRW-5000 (Japan) or newly released autorefractor, was undertaken to assess its repeatability and validity compared to subjective refraction. It is a valuable complement to subjective refraction and as it offers the advantage of a binocular open field of view, has a great potential benefit for accommodation.

T Rotsos et al. (2009) ${ }^{13}$ Conducted a study to compare the accuracy of autorefractometer and traditional retinoscopy as a means of determining the approximate subjective refraction in children after cycloplegia and found that autorefractometer result under manifest and cycloplegic conditions show that the difference is considerably higher than the known differences reported earlier by means of conventional techniques. The same stands for the difference between the autorefractometer results under manifest conditions and the result under manual retinoscopy. They found a close agreement between result using the cycloplegic autorefractorometer and cycloplegic retinoscopy. Although the difference between the mean sphere obtained by the two methods was significant statistically, it was clinically insignificant. In this study the use of the autorefractometer without cycloplegia in children underestimated the true hyperopia and overestimated the true myopia with 
retinoscopy in 50-60\% in spherical equivalent and in $80-90 \%$ in cylindricntal values.

Pokupec $R$ et al (2013) ${ }^{14}$ In their they found that autorefractometer on narrow pupils has proven to be a method for detection of refractive errors in children. However, the exact value of the refractive error is obtained only in mydriasis with retinoscopy or an autorefractometer in dilated pupils.

\section{Conclusion}

We concluded from this study that autorefractometer over estimates refractive errors but there was no significant difference between wet retnoscopy and subjective acceptance So according to this study we suggest use of cycloplegic retnoscopy with subjective acceptance in determining refractive errors in children

\section{Bibliography}

1. Abrams D. Duke-Elder's Practice of Refraction. 1Oth ed. Philadelphia; Elsevier Science; 2002. p. 45-71.

2. Mohan K, Sharma A. Optimal dosage of cyclopentolate $1 \%$ for cycloplegic refraction in hypermetropes with brown irides. Indian J. Ophthalmol 2011; 59:5146.

3. Ramanjit S, Tandon R. Parsons' Diseases of the Eye. India: Elsevier India: 2011.

4. Elkington AR, Frank HJ, Greaney MJ. Clinical Optics. Oxford: Blackwell Scientific Publications; 1999

5. Murthy GV, Gupta SK, Ellwein LB, Munoz SR, Pokharel GP, SangaL, et al. Refractive error in children in an urban population in New Delhi. Invest Ophthalmol Vis Sei 2002;43:623-31.

6. Dandona R, Dandona L, Srinivas M, Sahare P, Narsaiah S, Munoz SR, et al. Refractive error in children in a ruralpopulation in India. Invest Ophthalmol Vis Sei 2002;43:615-22.

7. Shneor E, Millodot M, Avraham O, Amar $\mathrm{S}$, Gordon- Shaag A. Clinical evaluation of the L80 auto refractometer. Clin Exp Optom 2012;95:66-71.

8. Dahlmann-Noor AH, Comyn O, Kostakis V, Misra A, Gupta N, Heath J, et al. Plusoptix Vision Screener: The accuracy and repeatability of refractive measurements using a new autorefractor. Br J Ophthalmol 2009;93:346-9.

9. Funarunart $P, \quad$ Tengtrisom $S$, Sangsupawanich P, Siangyai P. Accuracy of noncycloplegic refraction in primary school children in Southern Thailand. J Med Assoc Thai 2009;92:806-11.

10. Jorge J, Queiros A, Almeida JB, Parafita MA. Retinoscopy/ autorefraction: which is the best starting point for a noncycloplegic refraction? Optom Vis Sei 2005;82:64-8.

11. Jorge J, Queiros A, Gonzälez-Meijome J, Femandes P, Almeida JB, Parafita MA. The influence of cycloplegia in objective refraction. Ophthalmie Physiol Opt 2005;25:340-5.

12. Mallen EA, Wolffsohn JS, Gilmartin B, Tsujimura S. Clinical evaluation of the Shin Nippon SRW5000 autorefractor in adults. Ophthalmie Physiol Opt. 2001 ;21:101-1.

13. TRotsos, Grigoriou D, Kokkolaki A, Manios N. A comparison of manifest refractions, cycloplegic refractions and retinoscopy on the RMA-3000 autorefractometer in children aged 3 to 15 years. Clinical ophthalmology (Auckland, NZ). 2009;3:42907.

14. Pokupec R, Mrazovac D, PopvicSuic S, Mrazovac V, Kordic R, Petricek I. Comparison between refractometer and retinoscopy in determining refractive errors in children. Coll Antropol. 2013 Apr; 37 Suppl 1:2058. 